\title{
PERCEPTION AND IDENTITY
}




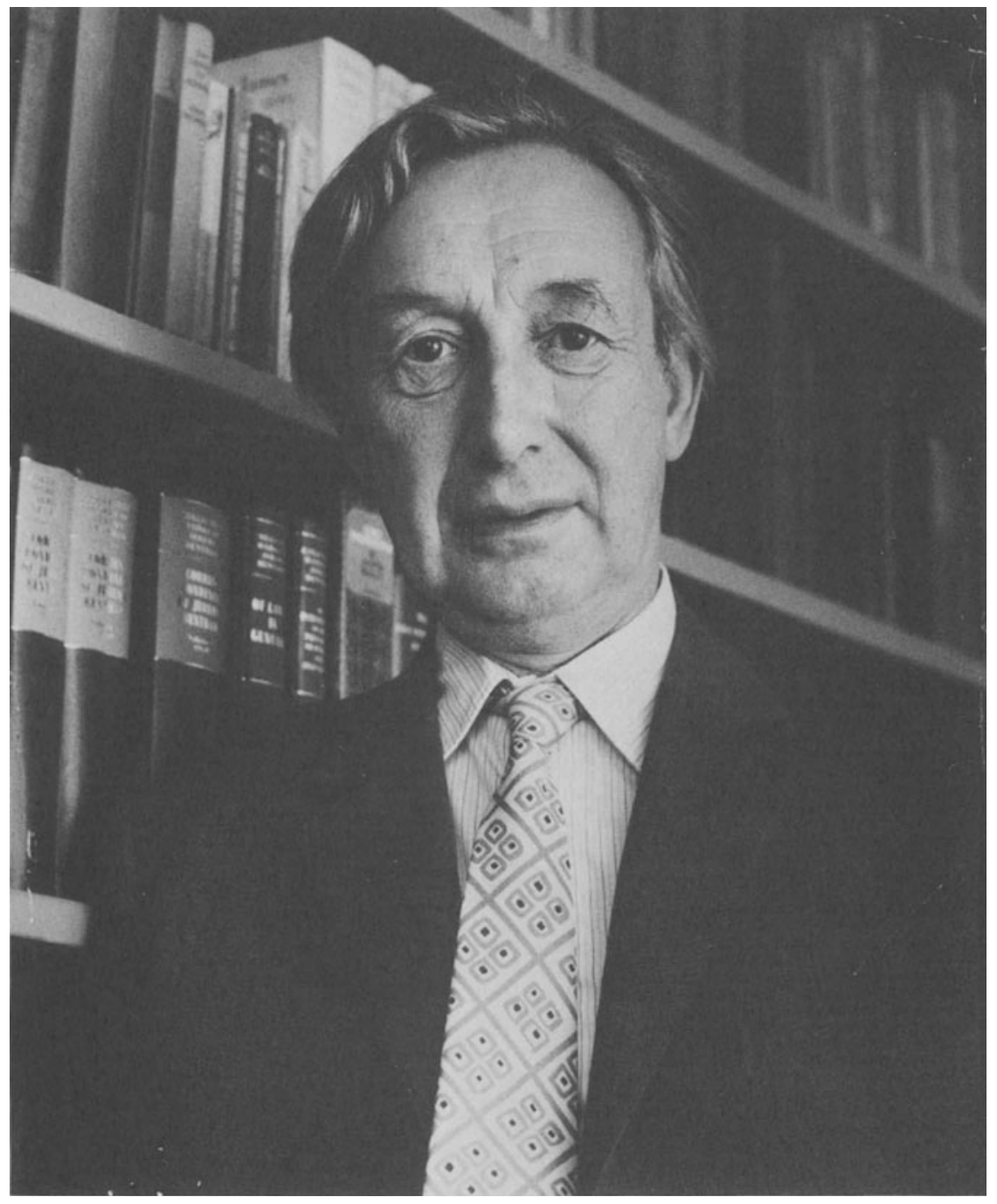




\title{
PERCEPTION AND IDENTITY
}

Essays Presented to A. J. Ayer with his Replies to them

\author{
edited by \\ G. F. MACDONALD
}


C) Graham Macdonald, Michael Dummett, P. F. Strawson, David Pears, D. M. Armstrong, Charles Taylor, J. L. Mackie, David Wiggins, John Foster, Richard Wollheim, Peter Unger, Bernard Williams, Stephan Körner and A. J. Ayer 1979.

Softcover reprint of the hardcover 1st edition 1979 978-0-333-27182-7

All rights reserved. No part of this publication may be reproduced or transmitted, in any form or by any means, without permission.

First published 1979 by

THE MACMILLAN PRESS LTD

London and Basingstoke

Associated Companies in Delhi, Dublin,

Hong Kong, Johannesburg, Lagos, Melbourne, New York, Singapore and Tokyo

Typeset by Santype International Limited, Salisbury, Wilts.

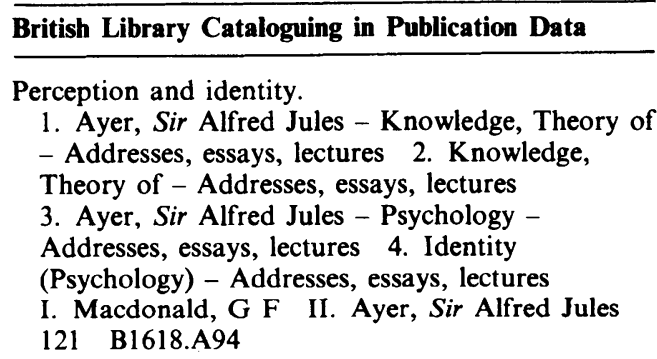

ISBN 978-1-349-04864-9 ISBN 978-1-349-04862-5 (eBook)

DOI 10.1007/978-1-349-04862-5

This book is sold subject to the standard conditions of the Net Book Agreement. 


\section{Contents}

Introduction GRAHAM MACDONALD vii

1. Common Sense and Physics Michael Dummett 1

2. Perception and its Objects P. F. Strawson 41

3. A Comparison between Ayer's Views about the Privileges of Sense-Datum Statements and the Views of Russell and Austin David Pears

4. Perception, Sense Data and Causality D. M. ARMSTRONG

5. Sense Data Revisited Charles TAYlor

6. A Defence of Induction J. L. MACKIE

7. Ayer on Monism, Pluralism and Essence DAviD WIGGINS

8. In Self-Defence JoHN FosTER

9. Memory, Experiential Memory and Personal Identity RichaRd WOLLHEIM

10. I Do Not Exist Peter Unger

11. Another Time, Another Place, Another Person BERNARD Williams

12. Ayer on Metaphysics StePhan KöRNER 262

13. Replies A. J. AYer

The Philosophical Works of A. J. Ayer 334

Bibliography 343

Notes on Contributors $\quad 347$

Index

We are grateful to the Radio Times and Don Smith for permission to reproduce the photograph of Sir Alfred Ayer on the frontispiece. 


\section{Introduction}

\section{GRAHAM MACDONALD}

The twelve essays in this volume have been collected in honour of Professor Sir A. J. Ayer, who retired from the Wykeham Chair of Logic at the University of Oxford in 1978. It is generally acknowledged that Freddie has been a major figure in twentieth-century analytical philosophy, and the details of his philosophical career are sufficiently well known for it to be unnecessary to repeat the details here. He has, since the publication of Language, Truth and Logic in 1936, become internationally renowned for his forceful and rigorous analysis of important topics in philosophy, especially in the areas of epistemology, the philosophical foundations of probability, philosophy of science, and metaphysics. His writing has consistently exhibited an elegance and clarity attained by very few philosophers. In addition Freddie has the pedagogic gifts of patience and understanding, as his many students who have received sympathetic guidance will know.

The contributors to this volume were invited to write on any topic which Freddie has published. This gave them a wide choice, but the collection has benefited by the fact that most of the articles are in the area of either philosophy of perception or identity and personal identity. As a 'Festschrift' it is unusual in that the person honoured was invited to reply to the comments on, and criticisms of his work. It would have been a great pity to miss the opportunity of having Freddie's thoughts about the articles published, and the most appropriate place of publication seemed to be alongside the essays. I would like to thank the contributors for their co-operation and for the care which they took over their articles. Their quality is a fitting tribute to the immense contribution which Freddie has made to philosophy. 